\title{
Demographic, clinical, laboratory, radiological, and outcome features of possible and definitive COVID- 19 patients followed in Sivas Cumhuriyet University Pandemic Clinic, in Turkey
}

\section{Sivas Cumhuriyet Üniversitesi Pandemi Kliniğinde izlenen olası ve kesin COVID-19 hastalarının demografik, klinik, laboratuvar, radyolojik ve izlem sonuçları}

\author{
Aynur Enginin ${ }^{1 *}$, Sevill Ceyhan Doğan², Murșit Hasbek ${ }^{3}$
}

Department of Infectious Diseases and Clinical Microbiology, ${ }^{2}$ Department of Physical Medicine and Rehabilitation, ${ }^{3}$ Department of Medical Microbiology, Sivas Cumhuriyet University School of Medicine, Sivas, Turkey.

Corresponding author: Aynur Engin, MD, Department of Infectious Diseases and Clinical Microbiology, Sivas, Turkey

E-mail: enginay@cumhuriyet.edu.tr

Received/Accepted: February 01, 2021 / May 28, 2021

Conflict of interest: There is not a conflict of interest.

\section{SUMMARY}

Objective: The aim of this study is to evaluate the epidemiological, clinical, laboratory, and radiological characteristics of 63 possible and definite COVID-19 patients who were followed up and treated in Sivas Cumhuriyet University Pandemic Clinic in April and May, 2020.

Method: In this retrospective study, the diagnosis and treatment of the patients were made according to the Turkish Ministry of Health COVID-19 guidelines. Patients' age, gender, underlying diseases, routine blood tests, SARS-CoV-2 PCR test results, clinical characteristics, treatments and radiological findings of the patients were taken from the patient files.

Results: The age range of 63 patients was $18-87$ years, and the mean age was 43 years. 37 patients $(58.7 \%)$ were male, and $26(41.3 \%)$ were female. 25 patients had positive PCR test for SARS CoV-2. PCR negativity developed on the 3rd day at the earliest and the 20th day at the latest, with an average of 10 days. In 2 patients, the fluctuation was observed in the process of negativity of the PCR test. It was seen that the most complaint was cough and second one was shortness of breath. It was remarkable that most of our patients did not have a high fever. Of the patients, the mean white blood cell count was 6,663 and the neutrophil/lymphocyte ratio was average 2.25 . In 49 patients (77.8\%), lung lesions were detected with chest CT. The most common finding we detected with chest CT was bilateral multiple ground-glass areas. Hydroxychloroquine treatment was given to $90 \%$ of the patients. In addition to the standard treatment, $3.1 \%$ of the patients were given Favipiravir treatment.

Conclusions: In this study, epidemiological, clinical, laboratory and radiological characteristics of 63 COVID-19 cases followed in Sivas province were reported. Global collaboration and sharing data and experiences on COVID-19 is essential to managing the current pandemic process in the world.

Keywords: Covid-19; clinic features; case; Sivas; Turkey

\author{
Aynur Engin \\ Sevil Ceyhan Dogan \\ Murşit Hasbek
}

ORCID IDs of the authors: A.E. $0000-0002-8533-8793$ S.C.D. 0000-0003-1570-8848 M.H. 0000-0002-5217-8607 
ÖZET

Amaç: Bu çalışmanın amacı, Nisan ve Mayıs 2020 tarihleri arasında Sivas Cumhuriyet Üniversitesi Pandemi Kliniği'nde takip ve tedavi edilen 63 olası ve kesin COVID-19 tanılı hastanın epidemiyolojik, klinik, laboratuvar ve radyolojik özelliklerini değerlendirmektir.

Yöntem: Bu retrospektif çalışmada hastaların tanı ve tedavisi Sağlık Bakanlığı COVID-19 kılavuzuna göre yapıldı. Hastaların yaşı, cinsiyeti, altta yatan hastalıkları, rutin kan tetkikleri, SARS-CoV-2 PCR test sonuçları, hastaların klinik özellikleri, aldıkları tedaviler ve akciğer radyolojik bulguları hasta dosyalarından alındı.

Bulgular: Takip edilen 63 hastanın yaș aralığı 18-87 y1l olup ortalama yaș 43 y1l idi. Hastaların 37 (\%58,7)'si erkek, 26 (\%41,3)'sı kadındı. 25 hastada SARS-CoV-2 RT-PCR testi pozitifti. PCR negatifliği ortalama 10 günde olmak üzere en erken 3. günde, en geç 20. günde gelişti. 2 hastada PCR testinin negatifleşme sürecinde dalgalanma gözlendi. Hastalarımızda en sık görülen şikayet öksürüktü, ikinci sıklıkta nefes darlığı vardı. Hastalarımızın çoğunda ateş yüksekliğinin olmaması dikkat çekiciydi. Hastaların ortalama beyaz küre sayısı 6.663 'tü ve nötrofil/lenfosit oranı ortalama 2.25 idi. Hastaların 49 (\%77,8)'unda toraks bilgisayarlı tomografi (BT) ile akciğerde lezyon saptandı. En sik saptanan toraks BT bulgusu bilateral multipl buzlu cam görüntüsüydü. Hastalarımızın \%90'ına hidroksiklorokin tedavisi verildi. Standart tedaviye ek olarak, hastaların \%3.1'ine Favipiravir tedavisi verildi.

Sonuç: Bu çalışmada Sivas ilinde takip edilen 63 COVID-19 vakasının epidemiyolojik, klinik, laboratuvar ve radyolojik özellikleri bildirilmiştir. COVID-19 ile ilgili küresel işbirliği ve verilerin ve deneyimlerin paylaşılması, dünyadaki mevcut pandemi sürecini yönetmek için çok önemlidir.

Anahtar sözcükler: Covid-19; klinik özellikler; vaka; Sivas; Türkiye

\section{INTRODUCTION}

Pneumonia cases due to a new Coronavirus attracted attention in Wuhan, China, in December 2019. At the beginning of the pandemic, the new virus was called 2019-nCoV (2019 for the year of detection, $\mathrm{n}$ for novel and $\mathrm{CoV}$ for coronavirus). In the later pandemic period, on February 12, 2020, the novel coronavirus was renamed severe acute respiratory syndrome coronavirus 2 (SARS-CoV2). Furthermore, the disease associated with the new virus was named COVID-19. COVID-19 is short for "coronavirus disease 2019". The World Health Organization (WHO) declared the SARSCoV2 pandemic on March 11, 2020. The first COVID-19 patient in Turkey was also reported in March $2020^{1}$.

In a short period, the number of cases multiplied all over the world. The World Health Organization has reported that as of January 24, 2021, there are 98,280,844 confirmed cases of COVID-19 worldwide, and 2,112,759 patients died ${ }^{2}$.

Although our knowledge about COVID-19 disease is increasing day by day, many things are still unknown. There is no specific treatment for the disease. There are many publications on COVID19 in the literature. These publications can change or increase our knowledge concerning the disease every day. In this sense, it is crucial to report the clinical, laboratory, radiological, or epidemiological characteristics of the disease from various countries or patient groups with other characteristics (such as age, gender). This information obtained from the patient will undoubtedly contribute to a better understanding of the disease and the development of its treatment and diagnostic methods. This study aims to analyze the clinical, laboratory, epidemiological, and radiological characteristics of 63 possible and definite COVID-19 patients who were followed up and treated in Sivas Cumhuriyet University Pandemic Clinic and to share our experience with the science world.

\section{MATERIAL AND METHODS}

Sixty-three probable and definite diagnosed adult COVID-19 patients hospitalized in the Pandemic service of Sivas Cumhuriyet University in April and May 2020 who were followed up and treated by us were included in the study. Our university doctors and nurses in Sivas Cumhuriyet University Pandemic Clinic monitored these patients, whom we followed up by assignment, on the 5th, 6th, and 7th floors of Sivas Numune Hospital B Block. Routine blood and radiological tests of the patients were performed at Sivas Numune hospital, and polymerase chain reaction (PCR) assay for diagnosis of COVID-19 was conducted in the microbiology laboratory of Sivas Cumhuriyet University Faculty of Medicine. Reversetranscription polymerase chain reaction (RT-PCR) assay to detect SARS-CoV-2 RNA from the upper respiratory tract was performed in all patients. Firstly, a pharyngeal swab specimen was received by the clinician for the diagnosis of COVID-19 on admission. Real-time RT-PCR assays for SARSCoV-2 RNA extraction was performed using Biospeedy extraction kit (Bioeksen Sariyer, Istanbul, Turkey). Real-time PCR was performed using Bio- 
speedy COVID-19 RT-qPCR detection kit with Rotor-Gene Q (QIAGEN, Hilden, Germany) Realtime PCR system.

This study is a retrospective study. Since it was a retrospective study, consent was obtained from the patients whom we could reach. Approval for this study was obtained from the Turkish Ministry of Health Scientific Research Platform (Form Name: Aynur Engin-2020-05-12T14_38_37) and Sivas Cumhuriyet University Non-Interventional Clinical Research Ethics Committee (Decision No: 2020-05/03). Besides, permission was obtained from the T.R. Sivas Governorship Provincial Health Directorate (24.06.2020 date, number: 76728045-799) for the study.

Age, gender, underlying diseases of the patients, routine blood tests (such as liver enzymes, BUN, creatinine, hemogram, D-dimer, CRP), PCR results for COVID-19, clinical features of the patients, the treatments they received, and lung radiological findings (PA chest X-ray and chest computed tomography) were taken from the patient files and recorded. The diagnosis, follow-up, and treatment of the patients were made according to the Ministry of Health's COVID-19 guideline available during the period when the patients were followed ${ }^{3}$. In this guideline, blood lymphocyte count $<800 / \mu \mathrm{l}$ or CRP $>40 \mathrm{mg} / \mathrm{l}$ or ferritin $>500 \mathrm{ng} / \mathrm{ml}$ or D-Dimer $>1000 \mathrm{ng} / \mathrm{ml}$ are indicated as poor prognostic criteria in blood tests taken at the time of application. Consequently, these blood values of our patients were examined in our study.

The study data were uploaded to the SPSS (Ver:22.0) program and were specified with frequency distributions and descriptive measures in the form of mean, standard deviation, number of individuals, and percentages.

\section{RESULTS}

The age range of 63 patients included in the study was $18-87$ years, and the mean age was $43.3 \pm 17.4$ years. There were seven patients aged 65 and over. When all possible and definite cases were taken in terms of gender distributions, 37 of the patients were male $(58.7 \%)$, and $26(41.3 \%)$ were female. Of the 25 patients with a positive RT PCR test for SARS-COV-2, 13 were female, and 12 were male. The average hospital stay of the patients was seven days (min 4-max 18 days). No patients died. Only one patient was transferred to intensive care and was taken back to the service in the next period.

Of the 63 adult patients included in this study, 25 (39.7\%) were definitively diagnosed with COVID19. RT-PCR for the SARS-CoV-2 RNA test of these patients was positive. After this, the RT PCR test for SARS-COV-2 RNA will be briefly stated as PCR or COVID-19 PCR test in the manuscript. The COVID-19 PCR test was positive in the first nasopharyngeal swab sample of 21 patients but negative in the first sample in 4 patients and positive in the second sample taken 24 hours later.

$38(60.3 \%)$ patients in our study were patients with probable COVID-19 diagnosis. In the nasopharyngeal swab sample of these patients, the COVID-19 PCR test was negative. However, the clinical, epidemiological, and/or radiological findings were compatible with COVID-19 disease. Our patients were diagnosed with probable or definite COVID-19 based on the COVID-19 guideline of the Ministry of Health of the Republic of Turkey ${ }^{3}$.

In the nasopharyngeal swab samples of patients with positive COVID-19 PCR test, PCR negativity developed on the 3rd day at the earliest and the 20th day at the latest, with an average of 10 days. In 2 patients, the fluctuation was observed in the negative process of the PCR test. For instance, in one of our patients, the second PCR test performed after 14 days was negative. However, positivity was detected in the third PCR test performed two days after this test. Finally, the fourth PCR test performed was negative.

Seventeen of our patients (26.9\%) were diagnosed with COVID-19 during their contact follow-up period. These patients had a recent history of contact with their family members or a COVID-19 patient in their environment. Eight of 63 patients had come from abroad. Four of them came from Kuwait, three from Germany, and one from Balkan countries. COVID-19 PCR test was positive in all patients from Germany and Kuwait. The COVID19 PCR test of the patient who came after the Balkan tour was negative, but the patient was followed up as a possible cause due to suspicious lesions in lung tomography.

We also examined our COVID-19 patients we followed in terms of other underlying diseases. Forty-five (71.4\%) of our 63 patients had no other underlying disease. Nine patients had diabetes, 11 patients had hypertension, three patients had asthma, four patients had coronary artery disease, and one patient had epilepsy.

When we examined the patients' complaints, it was seen that the most common we followed up was cough. The second most common complaint was shortness of breath (Table 1). 
Table 1: Sixty-three patients' complaints at the time of admission to the hospital

\begin{tabular}{|l|l|l|}
\hline Symptom & N (Total 63) & \% \\
\hline Fever & 24 & 38.1 \\
\hline Cough & 43 & 68.3 \\
\hline Sputum & 7 & 11.1 \\
\hline A stinging sensation in the chest & 6 & 9.5 \\
\hline Shortness of breath & 32 & 50.8 \\
\hline Headache & 9 & 14.3 \\
\hline Body/joint pain & 12 & 19.0 \\
\hline Throat ache & 17 & 27.0 \\
\hline Taste disturbance & 4 & 6.3 \\
\hline Smell disorder & 4 & 6.3 \\
\hline Diarrhea & 6 & 9.5 \\
\hline Runny nose & 2 & 3.2 \\
\hline
\end{tabular}

It was remarkable that most of our patients did not have a high fever. High fever was detected in 24 patients $(38.1 \%)$; however, it was normal in 39 patients $(61.9 \%)$. Six of the patients we followed up with had diarrhea complaints during hospitalization. Diarrhea was developed in 4 patients during hospitalization. Oxygen saturation was low in only three patients $(4.8 \%)$.

We had four patients with both taste and smell disorders. It was noteworthy that all of these patients came from Kuwait. The COVID PCR test was positive in three of these patients; only one was negative. All of the patients with both smell and taste disorders were male. All had bilateral multiple ground-glass areas compatible with COVID-19 in their chest computed tomography (CT).

One of our female patients had taste disturbances, but there were no complaints about odor. This patient recently had come to Sivas from Istanbul. The COVID-19 PCR test of this patient with taste impairment was positive and it was reported that there were lesions compatible with COVID-19 in chest $\mathrm{CT}$ taken in the outer center.

During the follow-up, pain, redness, swelling, and warmth developed in the right toe of a male patient who was followed up at the hospital and had a positive COVID-19 PCR test. This lesion, which was thought to be cellulite at first, regressed and disappeared in a short time. As our information on the disease increased in the following days, it was assumed that this lesion was an acral lesion related to COVID.

The posterior-anterior standard chest radiograph (PA chest X-ray) was normal for most of the patients. Still, there were lesions compatible with COVID-19 in chest CT in these patients. There were only $14(22.2 \%)$ patients with lesions on the PA chest X-ray; the films of 41 patients $(65.1 \%)$ were evaluated as normal, eight patients $(12.7 \%)$ did not have PA chest X-ray. The most common chest $\mathrm{CT}$ finding in the 63 COVID-19 patients we followed was bilateral multiple ground-glass opacity (Table 2). All but five patients with positive COVID-19 PCR tests were found to have lesions consistent with COVID-19 in lung tomography. The chest CT image from a COVID19 patient with positive COVID-19 PCR test is shown in Figure 1. Twenty-nine of the patients with negative COVID-19 COVID-19 PCR test had lesions compatible with COVID-19. A pulmonary CT scan of 9 patients with a negative PCR test was normal. 
Table 2: Chest CT findings of 63 patients

\begin{tabular}{|l|l|l|l|}
\hline Chest CT findings & $\begin{array}{l}\text { N (PCR + } \\
\text { patient) }\end{array}$ & $\begin{array}{l}\text { N (PCR - } \\
\text { patient) }\end{array}$ & Total \\
\hline Bilateral multiple ground-glass & 10 & 9 & 19 \\
\hline Ground-glass in right lung* & 1 & 3 & 4 \\
\hline Ground-glass in left lung* & 2 & 7 & 9 \\
\hline Normal & 5 & 9 & 14 \\
\hline Bilateral flagstone view & 1 & - & 1 \\
\hline Consolidation (in the right lung) & - & 4 & 4 \\
\hline Consolidation (in the left lung) & - & 1 & 1 \\
\hline Consolidation (bilateral) & 1 & 2 & 3 \\
\hline Subpleural millimetric nodule (in the left lung basal) & - & 1 & 1 \\
\hline Chest CT taken in outer center** & 3 & - & 3 \\
\hline $\begin{array}{l}\text { Unknown (chest CT was not taken or chest CT report could } \\
\text { not be reached) }\end{array}$ & 2 & 2 & 4 \\
\hline Total & 25 & 38 & 63 \\
\hline$*:$ single or multiple lesions & & & \\
\hline $\begin{array}{l}\text { **: Chest CT; Reported under COVID-19 but lesions not } \\
\text { described }\end{array}$ & & & \\
\hline
\end{tabular}

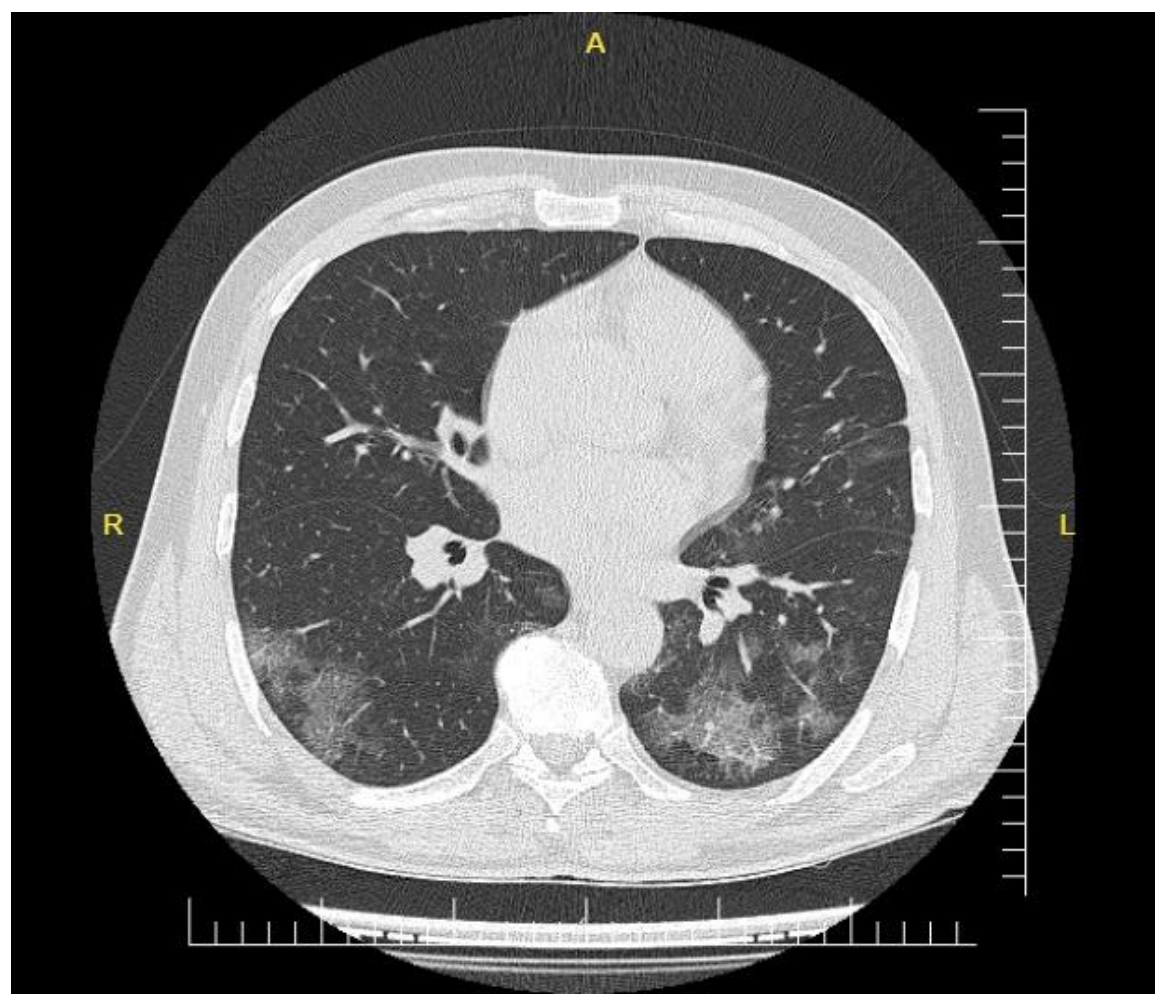

Figure 1: The chest CT image from a COVID-19 patient with positive PCR

Figure 1 legend. A 45-year-old male patient, he was hospitalized to our clinic with cough, sputum, shortness of breath, loss of taste and smell for 7 days. He was working in Kuwait for 10 months. He came back Turkey due to pandemic one day ago. PCR was positive for SARS CoV-2. In his chest computed tomography scan, bilateral, peripheral ground-glass opacities were seen in the lower lobes of lungs. 
Laboratory findings of 63 patients we followed up with a diagnosis of COVID-19 were evaluated. Some laboratory test results that are considered critical in disease follow-up are given in Table 3. Determination of D-Dimer level $>1,000 \mathrm{ng} / \mathrm{ml}$, CRP level $>40 \mathrm{mg} / \mathrm{l}$, blood lymphocyte count $<800 / \mu 1$, or ferritin level $>500 \mathrm{ng} / \mathrm{ml}$ in blood tests taken at the time of admission are considered as poor prognostic criteria for the disease ${ }^{[3]}$. The mean white blood cell count of 63 patients diagnosed with COVID-19 was 6,663 and was min 2,110-max 22,300 . Neutrophil/lymphocyte ratio was as $\min$ 0.93 -max 12.39, average 2.25. The lymphocyte count of 4 patients was 800 and/or below 800 .
Thrombocytopenia was detected in 6 patients. The lowest number of platelets in patients with thrombocytopenia was 95,000 . The D-dimer level was over $1,000 \mathrm{ng} / \mathrm{ml}$ in 10 of our patients. In 25 patients, the CRP level was found to be $40 \mathrm{mg} / \mathrm{l}$ and above. The highest CRP value detected in patients was 180 . Ferritin level was $500 \mathrm{ng} / \mathrm{ml}$ and above in 7 patients. Elevation of liver enzymes AST was detected in 7 patients, and ALT elevation was found in 9 patients. While the maximum value for AST was $119 \mathrm{U} / \mathrm{L}$, it was $146 \mathrm{U} / \mathrm{L}$ for ALT. We notice that the liver enzyme levels were not very high. Liver enzyme elevation was not more than three times the average value in any patient.

Table 3: Some laboratory values of all patients (probable and definite, $N=63$ )

\begin{tabular}{|l|l|l|}
\hline Laboratory test & $\mathrm{N}$ (have) & $\mathrm{N}$ (none) \\
\hline $\mathrm{CRP} \geq 40 \mathrm{mg} / \mathrm{l}$ & 25 & 38 \\
\hline D-dimer $\geq 1000 \mathrm{ng} / \mathrm{ml}$ & 10 & 53 \\
\hline Ferritin $\geq 500 \mathrm{ng} / \mathrm{ml}$ & 7 & 56 \\
\hline AST level (U/L) & 7 & 56 \\
\hline ALT level (U/L) & 9 & 54 \\
\hline Lymphocyte count $\leq 800 / \mu 1$ & 4 & 59 \\
\hline Thrombocytopenia & 6 & 57 \\
\hline
\end{tabular}

The patients' treatment was performed by the COVID-19 guidelines of the Ministry of Health of the Republic of Turkey ${ }^{3}$. Hydroxychloroquine treatment was given to 57 (90\%) of our 63 patients with a probable and definite diagnosis of COVID19 for five days. Before hydroxychloroquine treatment, ECG was taken in each patient, and treatment was initiated in those with average QT intervals. Hydroxychloroquine treatment was not given to 4 patients with normal chest CT findings and a good clinical picture. Two of our patients had previously been hospitalized with the diagnosis of COVID-19 and received hydroxychloroquine treatment. We did not give hydroxychloroquine treatment to these patients due to receiving it before. One of the patients who was hospitalized for the second time was admitted to our service for follow-up because shortness of breath complaints did not go away seven days after discharge. The other patient was admitted to our service for follow-up because complaints of weakness and loss of appetite continued ten days after the first hospitalization. Azithromycin was given to 53 (84\%) of 63 patients. There was no finding compatible with pneumonia in lung tomography of 8 patients; therefore azithromycin was not given to these patients. Also, azithromycin was not given to the 2 patients over since they had received it at their previous hospitalization. Favipiravir treatment was given to the 2 of 63 patients in addition to the standard treatment because of the clinical picture was severe, and oxygen saturation was low. Except for two patients, enoxaparin was administered as an anticoagulant drug to prevent the development of thromboembolism during their hospitalization. In addition to the standard treatment given for COVID-19, ampicillin-sulbactam was given to 6 patients, for whom the possibility of bacterial pneumonia could not be excluded. Seven patients were given moxifloxacin and one patient piperacillin-tazobactam treatment.

In the Ministry of Health's COVID-19 guide dated April 14, 2020, it was stated that corticosteroids should be avoided as much as possible in the treatment of adult patients but can be used in obligatory situations such as the development of acute respiratory distress syndrome. Routine use of corticosteroids was not recommended in treating 
COVID-19 in the early phase of the pandemic worldwide ${ }^{4}$. Accordingly, we avoided the use of corticosteroids in our patients unless necessary. Nevertheless, steroid administration was recommended by the pulmonology consultant for a patient with a diagnosis of asthma, whose general condition was impaired and dyspneic. Therefore, in addition to the current COVID-19 treatment, our patient was given methylprednisolone treatment at a dose of $40 \mathrm{mg} / \mathrm{day}$ for three days. This patient was previously transferred to intensive care and received Favipravir treatment. Interestingly, the patient's clinical condition improved significantly after corticosteroid use.

\section{DISCUSSION}

COVID-19 disease started in China in December 2019. It was declared a pandemic by the WHO on March 11, 2020, and the first case detected in Turkey occurred in the second week of March ${ }^{1}$. Today, it is seen that the number of patients has reached relatively high numbers both in the world and in our country. As of January 24, 2021 $98,280,844$ patients have been reported worldwide, and 2,112,759 patients have died ${ }^{2}$. In Turkey, a total of 2,457,118 patients have been reported on January 28, 2021, and 25,605 patients have died ${ }^{5}$. The epidemic continues, and our knowledge about the disease is increasing or changing day by day. There is currently no disease-specific drug. Therefore, disease prevention is essential.

COVID-19 disease can progress with many different complaints. It has been understood that the disease, which is thought to be characterized by fever, cough, and dyspnea in the first period of the epidemic, can occur in the later period with very different pictures such as taste and smell disorders, diarrhea, embolic events or myocarditis. When we look at the current situation, it is understood that COVID-19 disease is not only respiratory disease but also a systemic disease. Due to the ongoing epidemic process, our knowledge about the disease is continuously increasing.

The sensitivity of the PCR test used in the diagnosis of COVID-19 may vary depending on the test kit used, the technique of taking the sample, or the working center's experience. The first COVID-19 PCR test taken in 4 of our patients was negative, but the second PCR tests taken 24 hours later were positive. This situation shows us the importance of performing PCR tests at least twice in patients with suspected COVID-19. Besides, PCR test positivity may continue even if the patient's clinic improves. We found that PCR positivity continued for a maximum of 20 days in our patients. Another critical issue is the fluctuations that can be seen in the COVID-19 PCR test. This situation has also been reported in the literature ${ }^{6,7}$. In our study, we observed fluctuations in the PCR results of 2 different patients as positive, negative, positive, and negative (respectively). We consider this situation might be due to the virus's dynamics or whether the person who took the nasopharyngeal swab sample properly.

The sensitivity of the PCR test in the diagnosis of COVID-19 is not $100 \%$, and radiology is very important in diagnosis. PA chest X-ray of the patients may be normal, especially in the early period. Chest CT is more sensitive in detecting lesions in the lungs. It is particularly common in peripherally located multiple ground-glass areas in COVID-19 patients ${ }^{8}$. In our patient group, the most common finding we detected with chest CT was bilateral multiple ground-glass areas. PA chest Xray taken during hospitalization was normal in 41 $(65.1 \%)$ of the 63 patients in our study. However, in $49(77.8 \%)$ of our patients, lung lesions were detected with chest CT. In this respect, our study once again reveals the importance of chest $\mathrm{CT}$ in patients with suspected COVID-19.

In the 63 patients we followed up with, we found the most common complaints were cough and shortness of breath. However, fever was within normal limits in most of our patients. $\mathrm{Li}$ et al. reported that the main clinical symptoms of COVID-19 patients were fever (88.5\%) 9 . However, in our patient group, fever was only present in $38.1 \%$ of the cases. It was remarkable that most of our patients did not have a high fever. The rate of fever detection in COVID-19 patients may vary depending on the patients' age, the presence of comorbid conditions, and even the treatments given.

While diarrhea was not at the forefront of the epidemic at the beginning of the outbreak in COVID-19 patients, it started to be reported frequently in the following periods. When we look at the literature, it is observed that different rates of diarrhea complaints have been reported in further studies. Wei et al. reported that $31 \%$ of the patients with COVID pneumonia followed up complained of diarrhea ${ }^{10}$. However, $\mathrm{Li}$ et al. reported that the overall occurrence of diarrhea was $5.8 \%{ }^{11}$. Similarly, in Turkey, Sümer et al. stated that 5.4\% of COVID patients complained of diarrhea at admission ${ }^{12}$. Diarrhea was not a common complaint in the patients we followed up with. $9.5 \%$ of our patients had diarrhea complaints during hospitalization. In 4 of our patients (6.3\%), diarrhea developed during the follow-up after lying down. It was thought that the diarrhea complaint 
developed in these patients was primarily due to the side effects of the drugs used.

Some sensory disorders, like change in the sense of smell and/or taste shortly after the onset of COVID-19 pandemic, were reported. The frequency of smell and/or taste disorders in patients with COVID-19 shows a high variability from 5 to $98 \%{ }^{13}$. Roland et al. suggested that smell or taste change is a strong predictor for a COVID-19 positive test result. The authors reported that using the presence of smell or taste change with fever correctly predicts $75 \%$ of COVID-19 test results ${ }^{14}$. In our study, temporary loss of sense of smell and taste was $6.3 \%$ in the patients with COVID-19. So it was not a common complaint in our patients. Interestingly, the PCR test was positive in most of our patients with taste and smell disorders (3/4 of patients, 75\%). In our study, it was remarkable that all the patients with both taste and smell disorders had come from Kuwait. Actually, we do not know whether the viral strain in Kuwait is different from the viral strain in Turkey in our cases. However, the loss of sense of smell and/or taste in the patients may be related to Kuwait's viral strain.

Pain, redness, swelling, and warmth developed in the right big toe of a male patient who had a positive COVID-19 PCR test that we followed up in the hospital. In our patient, who was investigated for cellulite or gout, the lesion regressed in a short time. Our experience with skin manifestations associated with COVID-19 in the early phase of the outbreak was limited. Therefore, it was not thought that the current picture in the patient could be related to COVID-19. However, due to the increase in our knowledge of the disease and the literature review, we thought the patient's lesion was compatible with the acral lesion associated with COVID-19. Indeed, in the latter days of the pandemic, skin lesions similar to the lesion in our patient were reported. Ferrara and MorgadoCarrasco noted that cutaneous manifestations could be present in $20 \%$ of patients with COVID- $19^{15}$. The authors suggested that self- healing painful erythematous violaceous papules/plaques on acral locations (mostly on foot) can be related to COVID-19. Sachdeva et al. reported that the presence of painful acral red, purple papules was seen in $15.3 \%$ of patients with COVID-19 ${ }^{16}$. The authors notified that acral ischemic lesions presenting as red, purple papules were in patients with COVID-19. We believe that our patient's lesion was an acral ischemic lesion showing a redpurple papule or a self-healing painful erythematous lesion associated with COVID-19.

Another interesting observation of us is about the use of steroids in COVID-19 patients. In the early pandemic period, it was reported that given the lack of effectiveness and possible harm, routine corticosteroids should be avoided unless they are indicated for another reason ${ }^{3,4}$. However, in the later pandemic period, the preliminary results from the RECOVERY trial were announced. Recovery trial is a randomized controlled trial showing a significant reduction of death in ventilated patients and patients on supplemental oxygen therapy with dexamethasone. However, no benefit was observed in mild cases. According to the Recovery study, in the dexamethasone group, death incidence was lower than that in the usual care group among patients receiving invasive mechanical ventilation (29.3\% vs. $41.4 \%)$ and among those receiving oxygen without invasive mechanical ventilation $(23.3 \% \text { vs. } 26.2 \%)^{17}$. At present, dexamethasone is recommended in COVID-19, especially severe patients, or requiring supplemental oxygen therapy 18,19 .

When steroid use was not recommended for COVID-19 patients, we had to use corticosteroids on a patient due to her asthma. The patient needed supplemental oxygen therapy. She had a positive COVID-19 PCR test and a chest CT compatible with COVID-19. She had been treated at the intensive care unit (ICU) before being re-accepted to our clinic. She had also taken Favipiravir treatment at ICU. Her condition was not good for a long time, and she had shortness of breath. The chest diseases specialist we consulted suggested that steroids be given to the patient. However, we had some hesitations about giving steroids due to COVID-19. Eventually, we decided to follow the chest physician's suggestion. The patient's clinical condition who was given $40 \mathrm{mg} / \mathrm{day}$ methylprednisolone systemically for three days, improved rapidly. To be honest, this was surprising for us at the time.

Especially lymphocyte count and D-dimer level are critical in laboratory findings of COVID-19 patients. Monitoring of serum D-dimer levels is vital in terms of coagulopathy management in patients. In our study, only 10 of 63 patients had Ddimer levels above $1,000 \mathrm{ng} / \mathrm{ml}$. The fact that most of our patients are young and the absence of concomitant diseases may be effective in the relatively good clinical and laboratory findings.

$45(71.4 \%)$ of the 63 patients we followed up with did not have any underlying disease. The low number of elderly patients and the absence of underlying comorbid diseases (concomitant diseases) may be the reasons for our patients' good clinical prognosis. 
When we examined the disease's transmission route, we saw that it is crucial to contact a COVID19 diagnosed patient without a mask or to be in crowded environments such as weddings or funeral ceremonies in the family or work environment. We had cases in which many patients were identified from the same family members and relatives after attending a funeral. A female patient living in Sivas recently had a wedding. The man whom this patient married was a relative from Germany. After the wedding, the bride's father was diagnosed with COVID-19 and passed away. After her father's death, the bride, the bride's two sisters, the bride's mother, and the groom from Germany were admitted to our service with a possible COVID-19 pre-diagnosis. COVID-19 PCR test was negative in these patients. However, the mother complained of a cough. Multiple ground-glass areas were detected in both lungs in her chest CT, consistent with COVID-19. The bride's sister complained of cough and shortness of breath, but there was no lesion in her chest CT. In addition to the complaints of shortness of breath and diarrhea in the other sister of the bride, a patchy ground glass image was detected in the left lung in chest CT. The bride had a complaint of cough, headache, sore throat, and diarrhea. Chest CT revealed a small consolidation area in the left lung upper lobe anterior segment and a ground glass density around it. There was no complaint in the groom, and chest CT was normal. These two examples yet again show us the importance of crowded environments such as funerals and wedding ceremonies in the transmission of the disease in epidemic control.

To the best of our knowledge, this study is the first study to report the clinical, demographic, and radiological findings of COVID-19 patients followed in a hospital in Sivas province of Turkey. However, our study has some limitations. The small number of the patients is one of the limitations. In addition, it was not possible to comment on the effectiveness of some drugs such as hydroxychloroquine, since there was no control group. However, we believe that this study is noteworthy because it presents our experiences in the early phase of the pandemic.

Consequently, COVID-19 is a new disease, and despite our increasing experience, there is still much unknown about it. During this process, there may be changes in our current information from time to time. Clinicians learn some further knowledge (on diagnosis, pathogenesis, treatment, etc.) on the road during the COVID-19 pandemic process. Moreover, we do not encounter such a situation very often. Global collaboration and sharing data and experiences on COVID-19 and
SARS-CoV2 are essential to managing the current pandemic process in the world.

\section{REFERENCES}

1. Demirbilek Y, Pehlivantürk G, Ozgüler ZO, Alp Mese E. COVID-19 outbreak control, example of ministry of health of Turkey. Turk J Med Sci 2020;50:489-494.

2. World Health Organization. Weekly epidemiological update - 27 January 2021. Available from: https://www.who.int/publications/m/item/week ly-epidemiological-update---27-january-2021 (Accessed January 29, 2021).

3. The Turkish Ministry of Health, General Directorate of Public Health. COVID-19 (SARS-CoV-2 infection) Guide. Scientific Committee Study, 14 April 2020. (In Turkish: T. C. Sağlık Bakanlığı Halk Sağlığı Genel Müdürlüğ̈̈. COVID-19 (SARS-CoV-2 enfeksiyonu) rehberi, Bilim Kurulu Çalışması, 14 Nisan 2020). Available from: https://www.fip.org/files/content/priorityareas/coronavirus/moresources/Turkey_SARSCoV2InfectionGuide. pdf (Accessed October 19, 2020).

4. World Health Organization. Clinical management of severe acute respiratory infection (SARI) when COVID-19 disease is suspected: interim guidance, 13 March 2020. Available from: https://apps.who.int/iris/handle/10665/331446 (Accessed October 19, 2020).

5. The Turkish Ministry of Health, COVID-19 Information Page (Sağlık Bakanlığı COVID-19 Bilgilendirme Sayfas1). Available from: https://covid19.saglik.gov.tr (Accessed January 29, 2021).

6. Cento V, Colagrossi L, Nava A, et al. Persistent positivity and fluctuations of SARS-CoV-2 RNA in clinically-recovered COVID-19 patients. J Infect 2020;81(3):e90-e92.

7. Li Y, Yao L, Li J, et al. Stability issues of RTPCR testing of SARS-CoV-2 for hospitalized patients clinically diagnosed with COVID-19. J Med Virol 2020;92(7):903-908.

8. Wan S, Li M, Ye Z, et al. CT Manifestations and Clinical Characteristics of 1115 Patients with Coronavirus Disease 2019 (COVID-19): A Systematic Review and Meta-analysis. Acad Radiol 2020;27(7):910-921.

9. Li LQ, Huang T, Wang YQ, et al. COVID-19 patients' clinical characteristics, discharge rate, 
and fatality rate of meta-analysis. J Med Virol 2020;92(6):577-583.

10. Wei XS, Wang X, Niu YR, et al. Diarrhea Is Associated With Prolonged Symptoms and Viral Carriage in Corona Virus Disease 2019. Clin Gastroenterol Hepatol 2020;18(8):17531759.e2.

11. Li XY, Dai WJ, Wu SN, Yang XZ, Wang HG. The occurrence of diarrhea in COVID-19 patients. Clin Res Hepatol Gastroenterol 2020;44(3):284-285.

12. Sümer S, Ural O, Aktug-Demir N, et al. Clinical and laboratory characteristics of COVID-19 cases followed in Selcuk University Faculty of Medicine. Klimik Derg. 2020; 33(2): 122-7. Turkish.

13. Mullol J, Alobid I, Mariño-Sánchez F, et al. The Loss of Smell and Taste in the COVID-19 Outbreak: a Tale of Many Countries. Curr Allergy Asthma Rep 2020;20(10):61.

14. Roland LT, Gurrola JG 2nd, Loftus PA, Cheung SW, Chang JL. Smell and taste symptom-based predictive model for COVID-19 diagnosis. Int Forum Allergy Rhinol 2020;10(7):832-838.

15. Ferrara G, Morgado-Carrasco D. Visual Dermatology: Acral Erythemato-purpuric Lesions During COVID-19 Pandemic. J Cutan Med Surg 2020;24(4):409.
16. Sachdeva M, Gianotti $R$, Shah $M$, et al. Cutaneous manifestations of COVID-19: Report of three cases and a review of literature. J Dermatol Sci 2020;98(2):75-81.

17. RECOVERY Collaborative Group, Horby P, Lim WS, Emberson JR, et al. Dexamethasone in Hospitalized Patients with Covid-19 Preliminary Report. N Engl J Med 2020:NEJMoa2021436.

18. COVID-19 Treatment Guidelines Panel. Coronavirus Disease 2019 (COVID-19) Treatment Guidelines. National Institutes of Health. Available from: https://www.covid19treatmentguidelines.nih.g ov/ (Accessed October 19, 2020).

19. The Turkish Ministry of Health, General Directorate of Public Health. COVID-19 (SARS-CoV-2 infection) Adult Patient Treatment. Scientific Committee Study, 09 October 2020. [In Turkish: T. C. Sağllk Bakanlığ1 Halk Sağlığı Genel Müdürlüğü. COVID-19 (SARS-CoV-2 enfeksiyonu), Erişkin Hasta Tedavisi. Bilim Kurulu Çalışması, 09 Ekim 2020]. Available from: https://covid19.saglik.gov.tr/TR-66926/eriskinhasta-tedavisi.html (Accessed October 18, 2020). 